\title{
HUBUNGAN COPING STRES TERHADAP KUALITAS HIDUP PENDERITA SKIZOFRENIA PADA MASA REMISI SIMPTOM
}

\author{
Stefani Ivana ${ }^{1)}$, Devi Jatmika ${ }^{2)}$ \\ Program Studi Psikologi Universitas Bunda Mulia \\ ${ }^{1}$ stefaniivana17@gmail.com, ${ }^{2}$ djatmika@bundamulia.ac.id
}

\begin{abstract}
Schizophrenia is a mental disorder characterized by the appearance of symptoms such as hallucinations and delusions. The decrease in the frequency and intensity of symptoms is also called the period of symptom remision. Excessive unresolved stress conditions associated with recurrence / reappearance of schizophrenia symptoms. Relapse can affect the quality of life in people with schizophrenia during remission of symptoms.The purpose of this study was to determine the relationship between stress coping with quality of life in people with schizophrenia period remission symptom. This research is a quantitative study with correlational approach. The design of this study used is cross sectional. This study enrolled 52 people with schizophrenia disorder during the remission of symptoms. The data were collected using an adapted questionnaire, the SQLS (Self-Report Quality of Life measure for people with Schizophrenia) and the COPE Brief. Data analysis was done by using Pearson correlation statistic technique. The results showed that there was no correlation between stress coping and quality of life in schizophrenic patients on remission of symptom ( $p=0,765, p>0,05)$. There is no relationship between coping stress and quality of life caused by many other factors that affect the quality of life, namely negative stigma, self-mastery, family support, socioeconomic, treatment factors.
\end{abstract}

Keywords: coping stress, quality of life, schizophrenia

\begin{abstract}
ABSTRAK
Skizofrenia merupakan gangguan jiwa yang ditandai dengan menculnya gejala seperti halusinasi dan delusi. Penurunan frekuensi dan intensitas dari gejala disebut juga masa remisi simptom. Kondisi stres berlebih yang tidak dapat diatasi berkaitan dengan kekambuhan / kemunculan kembali gejala-gejala skizofrenia. Kekambuhan sendiri dapat mempengaruhi kualitas hidup pada penderita skizofrenia masa remisi simptom. Tujuan dari penelitian ini adalah untuk mengetahui hubungan antara coping stres dengan kualitas hidup pada penderita skizofrenia masa remisi simptom. Penelintian ini merupakan peneltian kuantitatif dengan pendekatakn korelasional. Desain penelitian ini yang digunakan adalah cross sectional. Penelitian ini meliabatkan 52 orang dengan gangguan skizofrenia pada masa remisi simptom. Pengumpulan data dilakukan dengan menggunakan kuesioner yang diadaptasi, yaitu SQLS (Self-Report Quality of Life measure for people with Schizophrenia) dan Brief COPE. Analisa data dilakukan dengan menggunakan teknik statistik korelasi pearson. Hasil penelitian menunjukkan bahwa tidak terdapat hubungan antara coping stres dengan kualitas hidup pada penderita skizofrenia masa remisi simptom $(\mathrm{p}=$ $0,765, \mathrm{p}>0,05)$. Tidak terdapat hubungan antara coping stres dengan kualitas hidup disebabkan karena banyak faktor lain yang mempengaruhi kualitas hidup, yaitu stigma negatif, penguasaan diri, dukungan keluarga, sosioekonomi, faktor pengobatan.
\end{abstract}

Kata kunci: coping stres, kualitas hidup, skizofrenia

\section{PENDAHULUAN}

Hidup di kota yang padat penduduk dapat menjadi beban tersendiri untuk kesehatan mental, karena tingginya biaya hidup, serta persaingan sosial dan ekonomi yang ada di kota tak jarang membuat individu mudah mengalami stres (Anwar, 2017). Beban kerja yang tinggi, tekanan lingkungan dan sosial, ketidakpastian masa depan dapat menimbulkan stres, yang jika tidak ditangani dapat mengakibatkan gangguan jiwa (Anna, 2016). Berdasarkan hasil Riset Kesehatan Dasar
(Riskesdas) tahun 2013, untuk provinsi DKI Jakarta, prevalensi masyarakat yang mengalami gangguan jiwa berat (psikosis atau skizofrenia) mencapai 1,1 per mil. Hal tersebut menunjukkan ada sekitar 1-2 orang yang mengalami gangguan jiwa dari 1000 penduduk (RISKESDAS, 2013).

Skizofrenia adalah salah satu gangguan yang ditandai dengan gangguan proses berpikir, adanya ide-ide yang tidak logis, perhatian dan persepsi yang salah, kurang ekspresi emosional atau terkadang ekspresi tidak sesuai, gangguan dalam gerakan dan perilaku (Kring, Johnson, 
Davison, Neale, 2010). Pada orang normal, adanya keterkaitan antara pikiran, perasaan, dan perbuatan, tetapi pada pasien skizofrenia, antara pikiran, perasaan dan perbuatan tidak saling terkait (Simanjuntak, 2008). Seseorang dengan skizofrenia dapat menarik diri dari orang lain dan kenyataan sehari-hari, sering hidup dalam kepercayaan aneh (delusi) dan halusinasi (Kring, et al., 2010).

Berdasarkan teori psikodinamika, stres merupakan salah satu penyebab dari skizofrenia, namun hubungan antara stres dengan skizofrenia tidak begitu sederhana dan adanya faktor lain yang perlu dipertimbangkan. Faktor yang perlu dipertimbangkan adalah tingkat penyesuaian diri individu sebelum mengalami stres dan dukungan sosial yang dimiliki individu. Individu yang dapat menyesuaikan diri dengan baik dan yang memiliki pertahanan yang efektif akan menangani stres dengan lebih baik sehingga kecil kemungkinan mengalami gangguan jiwa. Begitu juga pada individu yang yang memiliki dukungan sosial lebih banyak kemugkinan kecil mengalami gangguan jiwa, dan akan cepat pulih seandainya mengalami gangguan jiwa (Semium, 2006).

National Alliance for the Mentally III Amerika Serikat yang menyatakan bahwa tingkat keberhasilan pengobatan skizofrenia saat ini sekitar 60 persen, jauh lebih tinggi dibandingkan dengan pasien penyakit jantung yang hanya 41-52 persen (Anna, 2014). Persentase keberhasilan pengobatan skizofrenia tergolong cukup tinggi, yang artinya bahwa orang yang mengalami gangguan skizofrenia memiliki peluang yang besar untuk pulih. Namun untuk mencapai keberhasilan pengobatan, seseorang yang mengalami gangguan skizofrenia perlu diberikan pengobatan secara tepat dengan mengkombinasikan terapi medis dan psikoterapi. Ketika dalam fase psikotik akut, penanganan yang tepat adalah dengan memberikan terapi medis melalui pemberian obat-obatan antipsikotik dan ketika gejala psikotik mulai berkurang, intervensi psikologis sudah dapat diberikan (Kring, et al., 2010).

Masa dimana simptom dari skizofrenia (seperti halusinasi dan delusi) sudah berkurang intensitas dan frekuensinya disebut juga masa remisi simptom. Masa remisi simptom ini sesuai dengan simptom-simptom dari skziofrenia residual. Pada skizofrenia residual umumnya terlihat beberapa gejala-gejala skizofrenia namun tidak begitu kuat dan simptom seperti halusinasi dan delusi tidak sering atau hanya samar-samar (Semium, 2006).

Ketika simptom-simptom dari skizofrenia sudah terkendali, penderita skizofrenia dapat kembali menjalankan perannya ditengah masyarakat. Peneliti melakukan komunikasi pribadi dengan tiga orang yang telah didiagnosa skizofrenia residual, yaitu IR, R, dan D. Ketiganya dalam masa remisi simptom, dimana gejala-gejala skizofrenia sudah berkurang intensitas dan frekuensinya. Saat ini, ketiganya telah kembali mejalankan aktivitas sehari-hari ditengah masyarakat.

Namun penderita skizofrenia yang telah pulih mungkin saja untuk mengalami kekambuhan, artinya frekuensi dan intensitas kemunculan gejala seperti halusinasi dan delusi meningkat. Ada beberapa sebab yang dapat mempengaruhi kekambuhan pada penderita skizofrenia, salah satunya adalah kondisi stres psikologis seperti mempunyai konflik dengan keluarga dan masyarakat sekitar, dan masalah pekerjaan. Chabungbam (2007) menjelaskan bahwa kekambuhan skizofrenia salah satunya berkaitan dengan adanya stres psikologi (dalam Muyasaroh, 2014). Hal tersebut sejalan dengan hasil komunikasi pribadi peneliti dengan IR, R, dan $\mathrm{D}$ yang menceritakan pengalaman masingmasing ketika mengalami kekambuhan kembali dimana gejala-gejala dari skizofrenia kembali muncul, seperti emosi yang kembali tidak terkendali.

Menurut data hasil komunikasi pribadi peneliti dengan IR, $\mathrm{R}$ dan $\mathrm{D}$ dapat terlihat bahwa berdasarkan status pekerjaan, baik yang telah bekerja maupun yang belum memiliki pekerjaan sama-sama memicu stres, namun stres yang timbul diakibatkan oleh permasalah yang berbeda. Seperti yang diceritakan oleh IR saat ini ia telah bekerja, dan hal yang membuatnya merasa stres saat ini terkait dengan rekan kerjaanya, misalnya dalam pembagian tugas. Ketika ia belum memiliki pekerjaan, yang membuat IR merasa stres adalah karena IR merasa malu dan iri kepada teman-temannya yang telah memiliki pekerjaan.

Berbeda dengan IR, $\mathrm{R}$ sebelumnya berwirausaha, namun dikarenakan suatu sebab, usaha yang dibangun $\mathrm{R}$ harus diambil alih oleh pihak lain. $\mathrm{R}$ menceritakan pada waktu $\mathrm{R}$ menjalani usaha, terdapat permasalahanpermasalahan yang membuat $\mathrm{R}$ merasa stres, seperti menghadapi perkataan-perkataan dari pelanggan yang menurut $\mathrm{R}$ terkadang 
menyakiti hatinya. Namun ketika sedang tidak memiliki pekerjaan seperti saat ini, stres yang dirasakan $\mathrm{R}$ dikarenakan tidak adanya penghasilan sehingga harus bergantung kepada orang tua dan sulitnya untuk mencari pekerjaan ataupun membangun usaha baru karena ketidaktersediaan modal.

D memiliki sebuah toko yang dikelola bersama dengan istrinya. D menceritakan bahwa hal yang membuatnya merasa stres terkait dengan permasalahan ekonomi, permasalahan dengan agen dan pelanggan. Kebutuhan yang meningkat, harus membayar pajak, penghasilan yang tidak menentu merupakan permasalah yang menjadi beban pikiran D. Terkait permasalahan dengan pelanggan adalah menangani pelanggan yang beragam serta keluhan dari pelanggan. Permasalahan dengan agen biasanya terkait dengan sulitnya mendapatkan barang yang hendak dijual. Permasalahan ekonomi yang membuat $\mathrm{D}$ stres karena sulitnya mencari rezeki namun kebutuhan meningkat.

Ketiganya, baik IR, R, maupun D telah menemukan cara yang dapat mereka gunakan untuk mengelola stres yang dialaminya. Berbagai cara yang dilakukan untuk mengelola stres dikenal dengan istilah coping stres. Coping melibatkan upaya perilaku untuk menguasai, mengurangi dan mentolerir tuntutan yang dibuat oleh stres (Weithen, et al., 2012). Individu memiliki cara yang berbeda-beda dalam mengatasi masalah yang dialaminya. Ini dapat terlihat dari hasil komunikasi pribadi peneliti dengan IR, R, dan D. Ketiganya melakukan strategi coping stres yang berbeda-beda. IR mengatasi stres dengan melakukan kegiatan keagamaan seperti berdoa dan juga IR merasa membutuhkan dukungan dari orang lain seperti rekan, keluarga ataupun dokter. Lain halnya dengan $\mathrm{R}$ yang mengatasi stres dengan mengeluarkan perasaan negatifnya yaitu dengan cara menulis buku harian dan $\mathrm{R}$ juga mencari informasi-informasi dari orang sekelilingnya untuk dapat membantunya menyelesaikan permasalahan yang ia hadapi. Sedangkan D, ketika menghadapi suatu masalah, cenderung membutuhkan pemahaman dari orang sekelilingnya.

Ketika penderita skizofrenia dapat mengatasi permasalahan yang membuatnya merasa stres, mereka dapat menjalankan perannya ditengah masyarakat dan hidup mandiri. Sebaliknya, ketika tidak dapat mengelola stres yang dialaminya dapat berakibat mengalami kekambuhan. Seperti yang dijelaskan oleh Chabungbam (2007) bahwa kekambuhan skizofrenia salah satunya berkaitan dengan adanya stres psikologis (dalam Muyasaroh, 2014). Kekambuhan yang terjadi tentunya memberikan dampak yang buruk bagi penderita skizofrenia masa remisi simptom.

Kualitas hidup skizofrenia adalah evaluasi subyektif penderita akan kesejahteraan dan kepuasan hidupnya terkait dengan kondisi fisik, psikologis, dan sosial dalam melaksanakan kegiatan sehari-hari pasca-diagnosis (dalam Fiona \& Fajriathi, 2013). Menurut Wilkinson dkk (2000), terdapat tiga aspek penting yang terkait dengan kualitas hidup pada penderita skizofrenia, yaitu psikososial, motivasi dan energi dalam beraktivitas, simptom serta efek pengobatan. Psikososial membahas berbagai masalah emosional, seperti perasaan kesepian, depresi atau putus asa, perasaan kesulitan untuk berbaur dengan situasi sosial, dan merasa takut akan masa depan. Motivasi dan energi membahas berbagai permasalahan motivasi dan aktivitas seperti kurang kemauan untuk melakukan sesuatu. Gejala dan efek samping membahas mengenai keluhan fisik yang disebabkan oleh pengobatan medis, seperti gangguan tidur, pandangan kabur, pusing, mulut kering.

Melihat permasalahan-permasalahan yang terjadi di Jakarta, permasalahan ekonomi, sosial, dan pekerjaan membuat individu mengalami stres, sedangkan stres yang berkepanjangan dan tidak dapat diatasi individu dapat menimbulkan kekambuhan kembali gejala skizofrenia. Dimana kekambuhan sendiri mempengaruhi kualitas hidup penderita skizofrenia. Untuk itu penting bagi penderita skizofrenia masa remisi simptom untuk mengelola stres yang dialaminya. Hal tersebut penting karena bila stres tidak diatasi dapat menimbulkan kekambuhan, dan kekambuhan dapat mempengaruhi kualitas hidup dari penderita skizofrenia. Dari fenomena yang ada, peneliti ingin melihat hubungan coping stres dengan kualitas hidup pada penderita skizofrenia masa 
remisi simptom yang tinggal di Jakarta dan bila ditinjau dari status pekerjaan, adakah perbedaan yang ditunjukan.

Penelitian serupa pernah dilakukan oleh Rubbyana di Surabaya. Peneliti tertarik untuk meneliti di Jakarta. Berbeda dengan Surabaya, Jakarta merupakan ibu kota, dimana penduduk Jakarta sangat heterogen yang terdiri dari berbagai daerah di Indonesia. Jakarta acap kali disebut sebagai miniatur Indonesia dimana penduduk dari segala macam suku bagsa dan agama hidup berdampingan (Jamil, 2017). Penelitian ini juga bersifat parametrik dengan jumlah subjek 52 orang.

\section{Coping Stres}

Stres adalah keadaan respon psikologis terhadap stressor internal atau eksternal yang mempengaruhi kesehatan mental dan fisik, perasaaan dan perilaku, serta kualitas hidup seseorang (APA Dictionary of Psychology, 2013). Coping stres didefinisikan sebagai usaha dalam bentuk pikiran dan perilaku yang terus diubah untuk mengelola tuntutan yang dinilai sebagai tantangan atau di luar sumber daya individu (Davey, 2014). Coping adalah strategi kognitif dan perilaku yang digunakan untuk mengelola tuntutan situasi ketika situasi tersebut dinilai membebani atau melebihi sumber daya seseorang atau mengurangi emosi negatif yang dan konflik yang disebabkan stres (APA Dictionary of Psychology, 2013). Klasifikasi coping strategi yang dikemukan oleh Carver, Scheier, Weintrub (dalam Harrington, 2011)

Active coping (coping secara aktif). Individu yang menlakukan coping ini mengambil langkah-langkah secara aktif untuk memperbaiki dampaknya, seperti mulai melakukan sesuatu secara langsung, meningkatkan usaha, dan mencoba untuk menjalankan usaha coping secara bertahap.

Planning(Perencanaan). Coping dilakuakan dengan cara berpikir tentang bagaimana mengatasi stressor, seperti munculnya action strategy, berpikir tentang apa langkah yang harus diambil dan cara terbaik untuk menangani masalah tersebut.

Seeking Instrumental Support (Mencari dukungan instrumental). Cara mengelola stres dengan berusaha untuk mencari dukungan berupa nasihat, bantuan, atau informasi dari orang lain.
Seeking Emotional Support (Mencari dukungan emotional). Usaha yang dilakukan untukmencari dukungan berupa dukungan moral, simpati, atau pemahaman dari orang lain.

Positive Reframing (Memaknai kembali secara positif). Positive reframing merupakan strategi coping dimana seseorang menafsirkan hal atau situasu yang membuat stres sebagai suatu hal yang positif. Strategi coping ini menyebabkan seseorang untuk terus aktif menyelesaikan masalah.

Acceptance (Menerima). Usaha yang dilakukan untuk mengurangi rasa stres dengan cara menerima keadaan atau situasi yang membuat stres.

Religion (Religius). Seseorang beralih ke agama saat sedang stres karena agama dianggap berfungsi sebagai sumber dukungan emosional, sebagai media untuk menginterpretasi kembali hal positif dan pertumbuhan, atau sebagai taktik mengatasi stresor.

Venting (Meluapkan Emosi). Kecenderungan untuk fokus pada apapun yang membuatnya terganggu dan untuk mengeluarkan perasaanperasaan tersebut.

Denial (Penyangkalan). Berusaha tidak percaya bahwa stresor ada atau mencoba untuk bertindak seolah-olah tidak ada stresor.

Behavioral disengagement (Pelepasan melalui perilaku). Berkurangnya usaha seseorang dalam menangani stresor, bahkan menyerah untuk mencapai tujuan yang terganggu stresor. Behavioral disengagement tercermin dalam fenomena yang dikenal dengan ketidakberdayaan.

Substance Use (Penggunaan Zat). Cara untuk mengelola stres dengan mengonsumsi narkoba tau meminum alkohol untuk menghindari pikiran tentangstresor.

Self Distraction (Mendistrak Diri). Usaha untuk mengatasi masalah yang dilakukan untuk mengalihkan perhatian dari pikiran mengenai stresor.

Humor (Hiburan). Coping dengan humor dilakukan dengan menceritakan atau 
melakukan hal-hal lucu untuk mengurangi beban pikiran.

Self Blame (Menyalahkan Diri Sendiri). Cara mengatasi masalah dengan mengkritik diri sendiri sebagai yang bertanggungjawab dalam situasi tersebut.

\section{Kualitas Hidup}

Menurut Wilkinson dkk, kualitas hidup pada penderita skizofrenia adalah evaluasi subyektif individu akan kesejahteraan dan kepuasan hidupnya terkait dengan kondisi fisik, psikologis, dan sosial dalam melaksanakan kegiatan sehari-hari pasca-diagnosis (dalam Fiona \& Fajriathi, 2013). Menurut Wilkinson terdapat 3 aspek yang mempengaruhi kualitas hidup seseorang yang mengalami gangguan skizofrenia, yaitu:

a. Psikososial

Membahas berbagai masalah emosional, misalnya merasa kesepian, depresi atau putus asa, perasaan kesulitan untuk berbaur dengan situasi sosial dan merasa takut akan masa depan.

b. Motivasi dan Energi

Membahas berbagai permasalahan motivasi dan aktivitas seperti kurang kemauan untuk melakukan sesuatu.

c. Gejala dan efek samping

Membahas isu seperti gangguan tidur, pandangan kabur, pusing, kedutan otot dan mulut kering, yang disebabkan oleh pengobatan medis.

Penelitian ini perlu dilakukan untuk kemajuan ilmu pengetahuan dalam meningkatkan kualitas hidup penderita skizofrenia. Hasil penelitian dapat berkontribusi bagi perkembangan ilmu psikologi klinis, khususnya yang berhubungan dengan coping stres dan peningkatan kualitas hidup pada penderita skizofrenia. Tujuan penelitian ini adalah untuk mengetahui ada atau tidaknya hubungan antara coping stres terhadap kualitas hidup penderita skizofrenia dalam masa remisi simptom.

\section{METODE PENELITIAN}

Penelitian ini menggunakan metode kuantitatif dengan pendekatan korelasional untuk dapat mengetahui hubungan antara coping stres dengan kualitas hidup. Desain penelitian yang digunakan dalam penelitian ini adalah crosssectional, dimana setiap subjek hanya diobservasi satu kali dan pengukuran variabel dilakukan pada saat pemeriksaan tersebut (Oktavia, 2015).

Populasi penelitian ini adalah penderita skzofrenia dalam masa remisi simptom di KPSI dan RSJ Soeharto Heerdjan. Total sampel dalam penelitian ini yaitu 52 orang, dimana sebanyak 30 orang digunakan untuk tahap uji coba.

Untuk menentukan sampel penelitian, peneliti menggunakan teknik purposive sampling yaitu teknik penentuan sampel dengan pertimbangan tertentu. Dalam penelitian ini, peneliti menetukan kriteria sampel sebagai pertimbangan dalam menentukan subjek, yaitu: Sebelumnya pernah didiagnosis skizofrenia oleh psikiater, sedikitnya selama 1 tahun intensitas dan frekuensi gejala halusinasi dan delusi sudah berkurang, dan sudah memasuki usia dewasa yaitu diatas 18 tahun.

Dalam penelitian ini, terdapat 2 variabel penelitian yaitu variabel bebas adalah coping stres, dan variabel terikat adalah kualitas hidup. Coping stres adalah usaha yang dilakukan individu untuk mengurangi situasi yang dianggap berbahaya dan membuatnya stres yang aakan diukur dengan menggunakan instrumen penelitian yang diadaptasi dari bahasa Inggris ke bahasa Indonesia, yaitu Brief COPE yang terdiri dari 28 butir pernyataan. Brief COPE mengukur berbagai strategi coping stres diantaranya yaitu, active coping, planning, seeking instrumental support, seeking emotional support, venting, religion, behavioral disengagement, self distraction, substance use, denial, self-blame, humor, positive reframing, dan acceptance. Berbagai strategi coping tersebut dikelompokan ke dalam 4 dimensi coping stres, yaitu Problem Solving (4 butir pernyataan), Seeking Social Support (8 butir pernyataan), Avoidance (10 butir pernyataan), dan Positive Thinking (6 butir pernyataan).

Kualitas hidup merupakan evaluasi subjektif mengenai kehidupan pribadi individu yang akan diukur dengan menggunakan instrumen penelitian yang diadaptasi dari bahasa Inggris ke bahasa Indonesia yaitu SQLS yang terdiri dari 30 butir pernyataan. SQLS mengukur 3 dimensi, yaitu psikososial (terdiri dari 15 butir pernyataan), motivasi (terdiri dari 7 butir pernyataan), dan simptom dan efek samping ( 8 butir pernyataan).

Uji validitas dan reliabilitas dilakukan pada 30 subjek penelitian. Uji validitas dilakukan dengan menggunakan perhitungan korelasi product moment sedangkan uji reliabilitas dilakukan dengan menggunakan cronbach's alpha. Semua data yang diperoleh diolah dengan bantuan SPSS yang kemudian dianalisa hasilnya oleh peneliti.

Dari hasil uji validitas pada instrumen Brief COPE dari total 28 butir pernyataan sebanyak 13 butir pernyataan dinyatakan valid dan 15 butir pernyataan dinyatakan gugur. Hasil uji Reliabilitas menunjukkan nilai Cronbach's Alpha dari Brief COPE adalah 0,777, yang artinya reliabel. Setelah menggugurkan butir pernyataan yang dinyatakan tidak valid, peneliti kembali menghitung validitas dan reliabilitas dimana nilai Cronbach's Alpha dari Brief COPE naik menjadi 0,827. Untuk validitas, 
nilai corrected item-total correlationpada setiap butir pernyataan Brief COPE antara 0,244-0,591.

Dari hasil uji validitas pada instrumen SQLS dari total 30 butir pernyataan sebanyak 22 butir pernyataan dinyatakan valid dan 8 butir pernyataan dinyatakan gugur. Nilai Cronbach's Alphadari SQLS adalah 0,899, yang artinya reliabel. Setelah menggugurkan butir pernyataan yang dinyatakan tidak valid, peneliti kembali menghitung validitas dan reliabilitas dimana nilai Cronbach's Alpha dari SQLS naik menjadi 0,918. Untuk validitas, nilai corrected item-total correlation pada setiap butir pernyataan SQLS antara 0,365-0,718.

Teknik analisa data yang digunakan adalah korelasi person. Teknik analisa tersebut tepat digunakan karena hasil uji normalitas menunjukan bahwa data berdistribusi normal. Uji normalitas dilakukan dengan menggunakan onesample kolmogorov-smirnov test.

\section{HASIL DAN PEMBAHASAN}

Dari total keseluruhan, subjek yang berjenis kelamin pria sebanyak 38 orang dengan persentase $73,08 \%$ dan sebanyak 14 orang berjenis kelamin wanita dengan persentase $26,92 \%$.

Berdasarkan usia, jumlah terbesar didominasi subjek yang berusia pada rentang 29-38 tahun yaitu sebanyak 22 orang dengan persentase $42,31 \%$. Subjek penelitian yang berusia antara 19 28 tahun sebanyak 11 orang dengan persentase $21,15 \%$. Untuk rentang usia 39-48 tahun sebanyak 12 orang dengan persentase $23,08 \%$. Selanjutnya pada rentang usia 49-58 tahun sebanyak 7 orang dengan persentase $13,46 \%$.

Subjek dengan pendidikan terakhir SD sebanyak 6 orang dengan persentase 11,54\%, pendidikan terakhir SMP sebanyak 10 orang dengan persentse $19,23 \%$, pendidikan terakhir SMA sebanyak 23 orang dengan persentase $44,23 \%$ dan pendidikan teakhir perguruan tinggi sebanyak 13 orang dengan persentase $25 \%$.

Dari total keseluruhan sebanyak 21 orang berstatus menikah dengan persentase $40,38 \%$ dan 31 orang berstatus belum menikah dengan persentase $59,62 \%$.

Berdasarkan status pekerjaan Ditinjau dari pekerjaan, terdapat subjek penelitian yang telah memiliki pekerjaan (sebagai karyawan, penjaga toko, petugas keamanan, dan relawan), belum bekerja, berstatus sebagai pelajar, wirausaha, maupun ibu rumah tangga (IRT). Dari berbagai pekerjaan subjek penelitian, peneliti membagi menjadi dua kelompok yaitu kelompok yang bekerja (yang telah memiliki pekrjaan, pelajar, dan wirausaha) dan yang belum/tidak bekerja (belum bekerja dan ibu rumah tangga). Kelompok telah memiliki pekerjaan sebanyak 27 orang dengan persentase $51,92 \%$ dan yang belum/tidak memiliki perkerjaan sebanyak 25 orang dengan persentase $48,08 \%$.

\section{Norma Coping Stres}

Rata-rata dari variabel coping stres adalah 36,13 dengan standart deviasi 6,29. Gambaran coping stres dianalisa berdasarkan norma yang terbagi dalam 4 kategori, yaitu sangat tinggi, tinggi, rendah, dan sangat rendah. Pembuatan norma dilakukan dengan menggunakan norma kelompok persentil 25, 50, dan 75 .

Tabel 1

Norma coping stres

\begin{tabular}{ccc}
\hline Kategori & Jumlah & Persentase \\
\hline Sangat Tinggi & 11 & $21,2 \%$ \\
Tinggi & 12 & $23,1 \%$ \\
Rendah & 13 & $25 \%$ \\
Sangat Rendah & 16 & $30,8 \%$ \\
\hline Total & $\mathbf{5 2}$ & $\mathbf{1 0 0} \%$ \\
\hline
\end{tabular}

Kelompok dengan persentase tertinggi berada pada kategori sangat rendah yaitu 30,8\% . Pada urutaan kedua adalah kategori rendah dengan persentase $25 \%$. Jadi dapat disimpulkan bahwa secara umum coping stres yang dilakukan oleh subjek penelitian dapat dikatakan rendah, artinya individu kurang mampu untuk mengelola stres yang dialaminya.

Tabel 2

Norma dimensi problem solving

\begin{tabular}{ccc}
\hline Kategori & Jumlah & Persentase \\
\hline Sangat Tinggi & 9 & $17,3 \%$ \\
Tinggi & 16 & $30,8 \%$ \\
Rendah & 13 & $25 \%$ \\
Sangat Rendah & 14 & $26,9 \%$ \\
\hline Total & $\mathbf{5 2}$ & $\mathbf{1 0 0} \%$ \\
\hline
\end{tabular}

Kelompok dengan persentase tertinggi berada pada kategori tinggi yaitu 30,8\%. Jadi berdasarkan norma, pada dimensi problem solving cenderung tinggi. Kesimpulan yang dapat diambil adalah banyak dari subjek penelitian yang melakukan coping stres dengan strategi problem solving, yaitu dengan secara aktif melakukan tindakan dan perencanaan untuk menyelesikan masalah yang dihadapinya.

Tabel 3

Norma dimensi seeking social support

\begin{tabular}{ccc}
\hline Kategori & Jumlah & Persentase \\
\hline Sangat Tinggi & 8 & $15,4 \%$ \\
Tinggi & 10 & $19,2 \%$ \\
Rendah & 14 & $26,9 \%$ \\
Sangat Rendah & 20 & $38,5 \%$ \\
\hline Total & $\mathbf{5 2}$ & $\mathbf{1 0 0} \%$ \\
\hline
\end{tabular}


Kelompok dengan persentase tertinggi berada pada kategori sangat rendah yaitu $38,5 \%$. Pada urutaan kedua adalah kategori rendah dengan persentase $26,9 \%$. Jadi berdasarkan norma, pada dimensi seeking sosial support rendah. Kesimpulan yang dapat diambil adalah banyak dari subjek penelitiaan yang mengatasi permasalahan yang dialaminya bukan dengan cara mencari dukungan sosial.

Tabel 4

Norma dimensi avoidance

\begin{tabular}{ccc}
\hline Kategori & Jumlah & Persentase \\
\hline Sangat Tinggi & 9 & $17,3 \%$ \\
Tinggi & 12 & $23,1 \%$ \\
Rendah & 12 & $23,1 \%$ \\
Sangat Rendah & 19 & $36,5 \%$ \\
\hline Total & $\mathbf{5 2}$ & $\mathbf{1 0 0} \%$ \\
\hline
\end{tabular}

Kelompok dengan persentase tertinggi berada pada kategori sangat rendah yaitu $36,5 \%$. Pada urutaan kedua adalah kategori rendah dan tinggi dengan persentase $23,1 \%$. Jadi berdasarkan norma, pada dimensi avoidance rendah. Kesimpulan yang dapat diambil adalah banyak dari subjek penelitiaan yang tidak menyelesaikan masalah yang dihadapinya dengan menggunakan strategi avoidance, yaitu dengan cara menyangkal atau menghindari masalah.

Tabel 5

Norma dimensi positive thinking

\begin{tabular}{ccc}
\hline Kategori & Jumlah & Persentase \\
\hline Sangat Tinggi & 7 & $13,5 \%$ \\
Tinggi & 17 & $32,7 \%$ \\
Rendah & 13 & $25 \%$ \\
Sangat Rendah & 15 & $28,8 \%$ \\
\hline Total & $\mathbf{5 2}$ & $\mathbf{1 0 0} \%$
\end{tabular}

Kelompok dengan persentase tertinggi berada pada kategori tinggi yaitu 32,7\%. Jadi berdasarkan norma, pada dimensi positive thinking cenderung tinggi. Kesimpulan yang dapat diambil adalah banyak dari subjek penelitian yang melakukan coping stres memaknai permasalah yang dihadapi sebagai suatu hal yang positif.

\section{Norma Kualitas Hidup}

Rata-rata dari variabel kualitas hidup adalah 65,9 dengan standart deviasi 13,83. Gambaran kualitas hidup dianalisa berdasarkan norma yang terbagi dalam 4 kategori, yaitu sangat tinggi, tinggi, rendah, dan sangat rendah. Pembuatan norma dilakukan dengan menggunakan norma kelompok persentil 25, 50, dan 75 .
Tabel 6

Norma kualitas hidup

\begin{tabular}{ccc}
\hline Kategori & Jumlah & Persentase \\
\hline Sangat Tinggi & 12 & $23,1 \%$ \\
Tinggi & 13 & $25 \%$ \\
Rendah & 14 & $26,9 \%$ \\
Sangat Rendah & 13 & $25 \%$ \\
\hline Total & $\mathbf{5 2}$ & $\mathbf{1 0 0} \%$ \\
\hline
\end{tabular}

Kelompok dengan persentase tertinggi berada pada kategori rendah yaitu 26,9\%. Pada urutan kedua adalah kategori rendah dan tinggi dengan persentase $25 \%$. Jadi dapat disimpulkan bahwa secara umum kualitas hidup subjek penelitian rendah, artinya individu memandang hidupnya kurang sejahtera dan kurang memuaskan.

Tabel 7

Norma dimensi psikososial

\begin{tabular}{ccc}
\hline Kategori & Jumlah & Persentase \\
\hline Sangat Tinggi & 12 & $23,1 \%$ \\
Tinggi & 14 & $26,9 \%$ \\
Rendah & 12 & $23,1 \%$ \\
Sangat Rendah & 14 & $26,9 \%$ \\
\hline Total & $\mathbf{5 2}$ & $\mathbf{1 0 0 \%}$ \\
\hline Pada dimensi & psikososial, gambaran
\end{tabular}

kualitas hidup dari subjek penelitian dapat dikatakan sedang karena tidak tergolong tinggi maupun rendah. Hal ini dapat dilihat dari persentase yang ditampilkan pada tabel diatas. Total dari kategori sangat tinggi dan kategori tinggi adalah 50\%. Total dari kategori redah dan sangat rendah juga $50 \%$.

Tabel 8

Norma dimensi motivasi dan energi

\begin{tabular}{ccc}
\hline Kategori & Jumlah & Persentase \\
\hline Sangat Tinggi & 8 & $15,4 \%$ \\
Tinggi & 9 & $17,3 \%$ \\
Rendah & 18 & $34,6 \%$ \\
Sangat Rendah & 17 & $32,7 \%$ \\
\hline Total & $\mathbf{5 2}$ & $\mathbf{1 0 0} \%$ \\
\hline
\end{tabular}

Kelompok dengan persentase tertinggi berada pada kategori rendah yaitu 34,6\%. Pada urutan kedua dalah kategori sangat rendah, yaitu $32,7 \%$. Jadi berdasarkan norma, pada dimensi motivasi dan energi dapat dikatakan rendah. Kesimpulan yang dapat diambil adalah banyak dari subjek penelitian memandang motivasi dan energi yang dimilikinya kurang. 
Tabel 9

Norma simptom dan efek samping

\begin{tabular}{ccc}
\hline Kategori & Jumlah & Persentase \\
\hline Sangat Tinggi & 13 & $25 \%$ \\
Tinggi & 10 & $19,2 \%$ \\
Rendah & 16 & $30,8 \%$ \\
Sangat Rendah & 13 & $25 \%$ \\
\hline Total & $\mathbf{5 2}$ & $\mathbf{1 0 0} \%$ \\
\hline
\end{tabular}

Kelompok dengan persentase tertinggi berada pada kategori rendah yaitu 30,8\%. Pada urutan kedua dalah kategori sangat rendah dan sangat tinggi, yaitu $25 \%$. Jadi berdasarkan norma, pada dimensi simptom dan efek samping dapat dikatakan rendah. Kesimpulan yang dapat diambil adalah banyak dari subjek penelitian merasa simptom dan efek samping dari obat yang dikonsumsinya mengganggu dalam kesehariannya.

\section{Hasil Uji Korelasi}

Sebelum melakukan uji hubungan peneliti melakukanuji asumsi denga menggunakan Onesample Kolmogorov-Smirnov Test untuk mengetahui normal atau tidaknya sebaran skor dari data. Hasil perhitungan dengan SPSS menunjukkan p untuk kelompok data coping stres adalah 0,477. Pada kelompok data kualitas hidup nilai $\mathrm{p}$ adalah 0,211. Dari hasil uji normalitas dapat disimpulkan bahwa sebaran skor pada kelompok coping stres maupun kualitas hidup adalah normal, sehingga data dapat dianalisa dengan menggunakan teknik statistik parametrik, yaitu korelasi pearson.

Hasil perhitungan dengan SPSS menunjukkan nilai $r=-0,042$ dengan signifikansi $p$ $=0,765$. Dilihat dari nilia $\mathrm{p}>0,05$ dapat diartikan bahwa tidak terdapat hubungan yang signifikan antara coping stres dengan kualitas hidup.

Tabel 10

Korelasi coping stres dengan dimensi kualitas hidup

\begin{tabular}{ccc}
\hline Dimensi & Nilaip & Nilai r \\
\hline Psikososial & 0,960 & $-0,007$ \\
Motivasi \& Energi & 0,259 & $-0,159$ \\
Simptom \& efek samping & 0,638 & $-0,067$ \\
\hline
\end{tabular}

Dari hasil perhitungan korelasi antara variabel coping stres dengan ketiga dimensi dari variabel kualitas hidup menunjukkan nilai p lebih besar dari (>) 0,05, yang artinya tidak terdapat hubungan yang signifikan antara coping stres dengan dimensi-dimensi dari kualitas hidup.

\section{Analisa Tambahan \\ Uji perbedaan dilakukan dengan menggunakan teknik statistik t-test. Nilai p akan}

menunjukkan ada atau tidak adanya perbedaan antara kedua kelompok data.

Tabel 11

Perbedaan coping stres subjek berdasarkan status pekerjaan

\begin{tabular}{ccc}
\hline Keterangan & $\mathbf{p}$ & $\mathbf{t}$ \\
\hline CopingStres & 0,067 & 1,87 \\
Problem Solving & 0,040 & 2,11 \\
Seeking Social Support & 0,439 & 2,11 \\
Avoidance & 0,881 & 0,78 \\
Positive Thinking & 0,016 & 2,51 \\
\hline
\end{tabular}

Berdasarkan uji perbedaan antara subjek yang bekerja dengan subjek yang belum bekerja, menunjukkan bahwa secara umum, tidak terdapat perbedaan antara coping stres pada subjek yang bekerja dengan subjek yang belum bekerja, karena $\mathrm{p}>0.05$.

Namun jika dilihat pada dimensi problem solving dan positive thinking, hasil menunjukkan bahwa terdapat perbedaan antara subjek yang bekerja dengan yang belum bekerja karena nilai $\mathrm{p}<$ 0,05 .

Peneliti juga ingin melihat perbedaan kualitas hidup pada subjek yang bekerja dengan subjek yang belum bekerja, berdasarkan nilai $\mathrm{p}$. Perhitungan rata-rata pada kedua kelompok akan menunjukkan kelompok mana yang cenderung lebih tinggi. Tabel berikut menunjukkan rata-rata dan nilai dari kedua kelompok.

Tabel 12

Perbedaan kualitas hidup subjek berdasarkan status pekerjaan

\begin{tabular}{ccc}
\hline Keterangan & $\mathbf{p}$ & $\mathbf{t}$ \\
\hline Kualitas Hidup & 0,269 & 1,118 \\
Psikososial & 0,306 & 1,035 \\
Motivasi \& Energi & 0,657 & 0,446 \\
Simptom \& Efek Samping & 0,248 & 1,169 \\
\hline
\end{tabular}

Dari hasil perhitungan uji perbedaan antara subjek yang bekerja dengan subjek yang belum bekerja, menunjukkan bahwa secara umum, tidak terdapat perbedaan kualitas hidup pada subjek yang bekerja dengan subjek yang belum bekerja. Pada dimensi-dimensi dari kualitas hidup juga tidak terdapat perbedaan antarasubjek yang bekerja dengan subjek yang belum bekerja. Hal ini terbukti dari nilai $\mathrm{p}>0,05$.

\section{DISKUSI}

Secara umum gambaran dari coping stres pada subjek penelitian dikatakan rendah, artinya individu kurang mampu untuk mengelola stres yang dialaminya. Dari dimensi-dimensi coping stres, pada dimensi problem solving dan positive thinking dikatakan cenerung tinggi, artinya bahwa kebanyakan subjek penelitian menyelesaikan 
permasalahan yang dialaminya dengan melakukan perencanaan dan tindakan secara aktif untuk menyelesaikan masalah serta memaknai permasalahan yang ia hadapi sebagai suatu hal yang positif. Pada dimensi seeking social support dan avoidance adalah rendah, artinya dalam mengatasi permasalahan yang dihadapi, individu cenderung untuk tidak mencari dukungan sosial dan tidak menyangkal / menghidari permasalahan yang ia alami.

Secara umum gambaran kualitas hidup subjek penelitian rendah, artinya individu memandang hidupnya kurang sejahtera dan kurang memuaskan. Dilihat dari dimensi kualitas hidup, pada dimensi psikososial dikatakan sedang, karena antara skor kelompok dengan skor tinggi dan kelompok dengan skor rendah setara. Pada kedua dimensi lainnya hasil menunjukkan adalah rendah.

Dalam penelitian ini, ingin melihat hubungan antara coping stres dengan kualitas hidup. Hasil penelitian menunjukkan bahwa tidak terdapat hubungan antara coping stres dengan kualitas hidup pada penderita skizofrenia. Dari hasil uji korelasi secara keseluruhan didapat nilai $\mathrm{p}$ $=0,765$, dimana $\mathrm{p}>0,05$ artinya tidak terdapat hubungan yang signifikan. Analisa hubungan antara coping stres dengan dimensi-dimensi dari kualitas hidup juga tidak menunjukkan hubungan yang signifikan karena nilai $\mathrm{p}>0,05$.

Hasil penelitian menunjukkan bahwa tidak terdapat hubungan yang signifikan antara coping stres dengan kualitas hidup. Hasil ini berbeda dengan penelitian dari Rubbbyana (2012) bahwa terdapat terdapat hubungan yang signifikan antara coping stres dengan kualitas hidup dengan arah yang positif. Dalam penelitian tersebut dijelaskan bahwa semakin tinggi coping adaptif yang dilakukan maka semakin tinggi pula kualitas hidup pada penderita skizofrenia masa remisi simptom (Rubbyana, 2012).

Hubungan antara coping stres dengan kualitas hidup penderita skizofrenia tidak berhubungan secara signifikan pada penelitian ini kemungkinan disebabkan bahwa adanya faktorfaktor lain yang mempengaruhi kualitas hidup selain coping stres. Sebuah penelitian yang dilakukan oleh Hsiung (dalam Fiona \& Fajrianthi, 2013) menunjukkan bahwa terdapat hubungan yang positif antara kualitas hidup dengan penguasaan diri dan juga terdapat hubungan yang negatif antara kualitas hidup dengan stigma negatif. Semakin baik penguasaan diri individu maka semakin baik pula kualitas hidupnya, sedangkan semakin tinggi stigma maka kualitas hidup semakin rendah. Penguasaan diri menurut Hsiung (dalam Fiona \& Fajrianthi, 2013) adalah sejauh mana individu melihat diri mereka dalam kekuatan (forces) yang mempengaruhi kehidupannya. Penderita skizofrenia yang memiliki penguasaan diri yang baik akan merasa dirinya lebih mandiri dan memiliki kontrol penuh akan dirinya sehingga ia dapat melakukan hal-hal yang disenanginya, dengan begitu penderita skizofrenia akan merasa lebih baik dan sejahtera yang kemudian membentuk kualitas hidup yang baik pula. Terkait dengan stigma negatif, dijelaskan bahwa lingkungan yang supportif membuat penderita skizofrenia merasa diterima di masyarakat dan dapat menjalin relasi sosial sehingga kualitas hidup penderita skizofrenia menjadi lebih baik (Fiona \& Fajrianthi, 2013).

Dari hasil uji perbedaan coping stres antara subjek yang berkerja dengan yang belum bekerja tidak menunjukkan adanya perbedaan. Namun ketika dilihat pada dimensi coping stres, terdapat perbedaan pada dimensi problem solving dan positive thinking. Subjek yang bekerja cenderung lebih tinggi pada dimensi problem solving dan positive thinking dibandingkan dengan subjek yang belum bekerja. Dari hasil perhitungan dan analisa tersebut, dapat disimpukan bahwa subjek yang bekerja lebih dapat melakukan tindakan secara aktif untuk menyelesaikan masalah dan lebih dapat berpikir secara positif ketika menghadapi masalah / mengalami stres.

Menurut Kessler dkk (2005) yang menyatakan bahwa orang yang bekerja memiliki rasa optimis terhadap masa depan dan lebih memiliki semangat hidup yang besar dibandingkan dengan orang yang tidak bekerja (Wijayanti dan Puspitosari 2014). Dengan adanya perasaan optimis dan semangat hidup juga membuat individu lebih berani untuk mengambil tindakan. Pada subjek yang bekerja lebih dapat berpikir secara positif ketika menghadapi masalah mungkin saja karena adanya semangat hidup dan perasaan optimis dalam diri individu.

Untuk kualitas hidup, hasil uji perbedaan menunjukkan tidak terdapat perbedaan antara subjek yang bekerja dengan subjek yang belum bekerja. Dari hasil tersebut dapat diartikan bahwa antara subjek yang bekerja dengan subjek yang belum bekerja memiliki kualitas hidup yang cenderung sama. Dilihat pada dimensi kualitas hidup juga tidak menunjukkan adanya perbedaan antara kedua kelompok, artinya dilihat dari psikososial, motivasi \& energi, serta simptom \& efek samping dari kedua kelompok cenderung sama. Tidak terdapatnya perbedaan antara subjek yang bekerja dengan subjek yang belum bekerja mungkin karena kualitas hidup penderita skizofrenia masa remisi simptom tidak hanya dipengaruhi oleh faktor dari status pekerjaan.

Menurut Wijayanti dan Puspitosari (2014) bahwa kualitas hidup penderita skizofrenia dipengaruhi oleh beberapa faktor, yaitu sosioekonomi, dukungan dari keluarga dan faktor pengobatan. Wijayanti dan Puspitosari (2014) menjelaskan bahwa penderita yang kualitas hidupnya tinggi adalah penderita yang melakukan 
pengobatan rutin dan adanya dukungan atau perhatian dari keluarga pasien. Lebih lanjut, dalam penelitian tersebut dijelaskanbahwa sebagian besar subjek penelitiannya yang mengalami gangguan jiwa adalah orang-orang dengan faktor ekonomi rendah, kurangnya kesadaran untuk berobat rutin, dan kurangnya dukungan dari keluarga.

\section{SIMPULAN DAN SARAN}

Secara umum, hasil analisa gambaran coping stres pada penderita skizofrenia dikatakan rendah yang artinya, kurang dapat mengelola stres yang dialaminya. Berdasarkan analisa yang dilakukan pada setiap dimensi, terlihat bahwa pada dimensi problem solving dan positive thinking cenderung tinggi, artinya banyak dari penderita skizofrenia yang menyelesaikan permasalahan yang dialaminya dengan cara memaknai permasalahan yang dihadapinya sebagai suatu hal yang positif serta melakukan tindakan secara aktif dan merencanakan penyelesaian masalah.

Berdasarkan hasil uji korelasi dapat disimpulkan bahwa tidak terdapat hubungan yang signifikan antara coping stres dengan kualitias hidup pada penderita skizofrenia. Tidak signifikannya hubungan antara copingstres dengan kualitas hidup kemungkinan disebabkan bahwa adanya faktor-faktor lain yang tidak dikontrol oleh peneliti, seperti sosioekonomi, dukungan dari keluarga, faktor pengobatan, dan penguasaan diri.

Berdasarkan analisa, terdapat perbedaan strategi coping stres yang digunakan subjek yang bekerja dengan subjek yang belum bekerja. Ini terlihat pada dimensi problem solving dan positive thinking, sehingga dapat disimpulkan bahwa subjek yang bekerja lebih dapat melakukan tindakan secara aktif untuk menyelesaikan masalah dan lebih dapat berpikir secara positif ketika menghadapi masalah / mengalami stres. Sedangkan pada kualitas hidup, hasil menunjukkan tidak ada perbedaan antara kualitas hidup subjek yang bekerja dengan subjek yang belum bekerja.

\section{Saran}

Saran untuk penelitian selanjutnya adalah mencari literatur lebih banyak lagi mengenai faktor yang mempengaruhi kedua variabel agar dapat lebih memberikan kontrol terhadap faktor-faktor tersebut. Seperti halnya dari segi usia, akan lebih baik jika lebih homogen (misalnya dengan memilih rentang usia dewasa madya/ dewasa awal), sehingga lebih dapat menggambarkan. Berkaitan dengan usia ini penting untuk dipertimbangkan karena tentunya subjek yang berada pada usia lebih muda akan memiliki coping stres yang berbeda dengan subjek yang usianya sudah lebih dewasa. Selain itu, perlu juga mengukur kognitif (contohnya dengan MMSE) dari subjek penelitian untuk memastikan, bahwa subjek berada dalam fase remisi simptom sehingga memungkinkan subjek untuk mengisi kuesioner dengan baik. Untuk uji reliabilitas Brief COPE, akan lebih baik jika diuji per dimensi, karena setiap dimensi mengukur hal yang berdeda-beda walaupun keempatnya sama-sama mengukur coping stres.

Saran untuk subjek penelitian adalah ketika sedang menghadapi masalah jangan sungkan untuk mencari bantuan dengan membicarakan kepada pihak yang dapat dipercaya untuk membantu menyelesaikan masalah yang sedang dihadapi. Dengan begitu akan mendapat banyak dukungan dan masukkan / saran yang berguna untuk membantu mengatasi permasalahan yang sedang dihadapi. Selain itu, tetap rutin mengonsumsi obat dan berkonsultasi ke psikolog/psikiater sehingga dapat menyampaikan keluhan yang dialami. Dengan rutin mengonsumsi obat dan menyampaikan keluhan ke psikiater/psikolog secara fisik, psikososial, serta motivasi dan energi (yang merupakan aspek-aspek dari kualitas hidup) dapat menjadi lebih baik.

Saran dari peneliti untuk keluarga adalah membantu menciptakan suasana yang positif bagi penderita skizofrenia, di mana anggota keluarga dapat saling memberikan dukungan sosial satu dengan yang lainnya. Hal tersebut dapat dimulai dengan meluangkan waktu setiap hari untuk saling bertukar cerita sehingga apabila terdapat anggota yang sedang mengalami masalah, anggota keluarga yang lain dapat mengetahui. Dengan begitu keluarga dapat memberikan dukungan sosial satu sama lain. Seperti yang telah dijelaskan dalam penelitian ini bahwa dukungan sosial merupakan salah satu cara yang dapat dilakukan oleh pihak lain (seperti keluarga) untuk membantu individu menyelesaikan masalah yang sedang dihadapinya.

\section{DAFTAR PUSTAKA}

Anna, L. K (2014, Oktober). Menahlukkan skizofrenia dan hidup mandiri. Kompas.com. Diunduh dari: http://lifestyle.kompas.com/read/2014/1 0/10/0705008/Menaklukkan.Skizofrenia .dan.Hidup.Mandiri

Anna, L. K. (2016, Oktober). Kecemasan kaum muda urban.Kompas.com. Diunduh dari: http://lifestyle.kompas.com/read/2016/1 0/11/180000423/kecemasan.kaum.muda .urban

Anwar, F. (2017, April). Hidup di kota besar rawan stres, begini saran psikolog. detikHelath. Diunduh dari: https://health.detik.com/read/2017/04/13 
/085603/3473407/763/hidup-di-kotabesar-rawan-stres-begini-saran-psikolog

American Psychiatric Association (2013). Diagnostic and statistical manual of mental disorder. US: American Psychiatric Publishing

Davey, G. (2014). Applied psychology. UK: Wiley-BlackWell

Fiona, K., \& Fajrianthi (2013). Pengaruh dukungan sosial terhadap kualitas hidup penderita skizofrenia. Jurnal Psikologi Kepribadian dan Sosial, 2(3), 106-113.

Gravetter, F. J., \& Wallnau, L. B. (2009). Statistics for the behavioral sciences eight edition. USA: Wadsworth Cengage Learning

Jamil, A. I., (2017, Desember). Jakarta Paling Intoleran? Faktanya Urbanisasi Tinggi Loh. Republika.co.id. Diunduh dari: http://m.republika.co.id/berita/duniaislam/islamnusantara/17/12/15/p0zmdk396-jakartapaling-intoleran-faktanya-urbanisasitinggi-lho

Kring, A. M., Johnson, S. L., Davison, G. C., Neale, J. M. (2010). Abnormal psychology eleventh edition. Asia: John Wiley \& Sons

Kumar, R. (2014). Research methodology. Singapore: Sage

Lahey, B. B. (2012). Psychology an introduction. New York: McGraw-Hill

Muyasaroh, H. (2014). Hubungan stres psikologis dengan frekuensi kekambuhan pada pasien skizofrenia di RSJ Grhasia DIY.

Nursalam (2008). Konsep \& metodologi penelitian ilmu keperawatan. Jakarta: Salemba Medika

Oktavia, N. (2015). Sistematika penulisa karya ilmiah. Yogyakarta: Deepublish
Badan Penelitian dan Pengembangan

Kesehatan (2013). Riset kesehatan dasar (Riskesdas). Diunduh dari:

http://www.depkes.go.id/resources/dow nload/general/Hasil\%20Riskesdas\%202 013.pdf

Rubbyana, U. (2012). Hubungan antara strategi koping dengan kualitas hidup pada penderita skizofrenia remisi simptom. Jurnal Psikologi Klinis dan Kesehatan Mental, 1(2)

Semium, Y. (2006). Kesehatan mental 3. Yogyakarta: Kanisius

Simanjuntak, J. (2008). Konseling gangguan jiwa \& okultisme. Jakarta: Gramedia

Siregar, S. (2013). Metode penelitian kuantitatif. Jakarta: Kencana Prenada Media Group

Sofia, R. D. (2014). Buku ajar keperawatan gerontik. Yogyakarta: Deepublish

Sudarmanto, G. R. (2005). Analisis regresi linear ganda dengan SPSS. Yogyakarta: Graha Ilmu

Sugiyono (2015). Statistika untuk penelitian. Bandung: Alfabeta

VandenBos, G. R. (2007). APA dictionary of psychology. Washington: American Psychiatric Publishing

Wijayanti, A.\& Puspitosari, W.A. (2014). Hubungan onset usia dan kualitas hidup penderita skizofrenia di wilayah kerja puskesmas Kasihan II Bantul Yogyakarta, 14(1), 47-53.

Wilkinson, G., Hesdon, B., Wild, B., Cookson, R., Farina, C., Sharma, V., Fitzpatrick, R., \& Jenkinson, C. (2000). Self-Report of quality measure for people with schizophrenia: the SQLS. The British Journal of Psychiatric. 